\title{
IMPACT OF THE PROPOSED I-326 CROSSING ON THE 500-YEAR FLOOD STAGES OF THE CONGAREE RIVER NEAR COLUMBIA, SOUTH CAROLINA
}

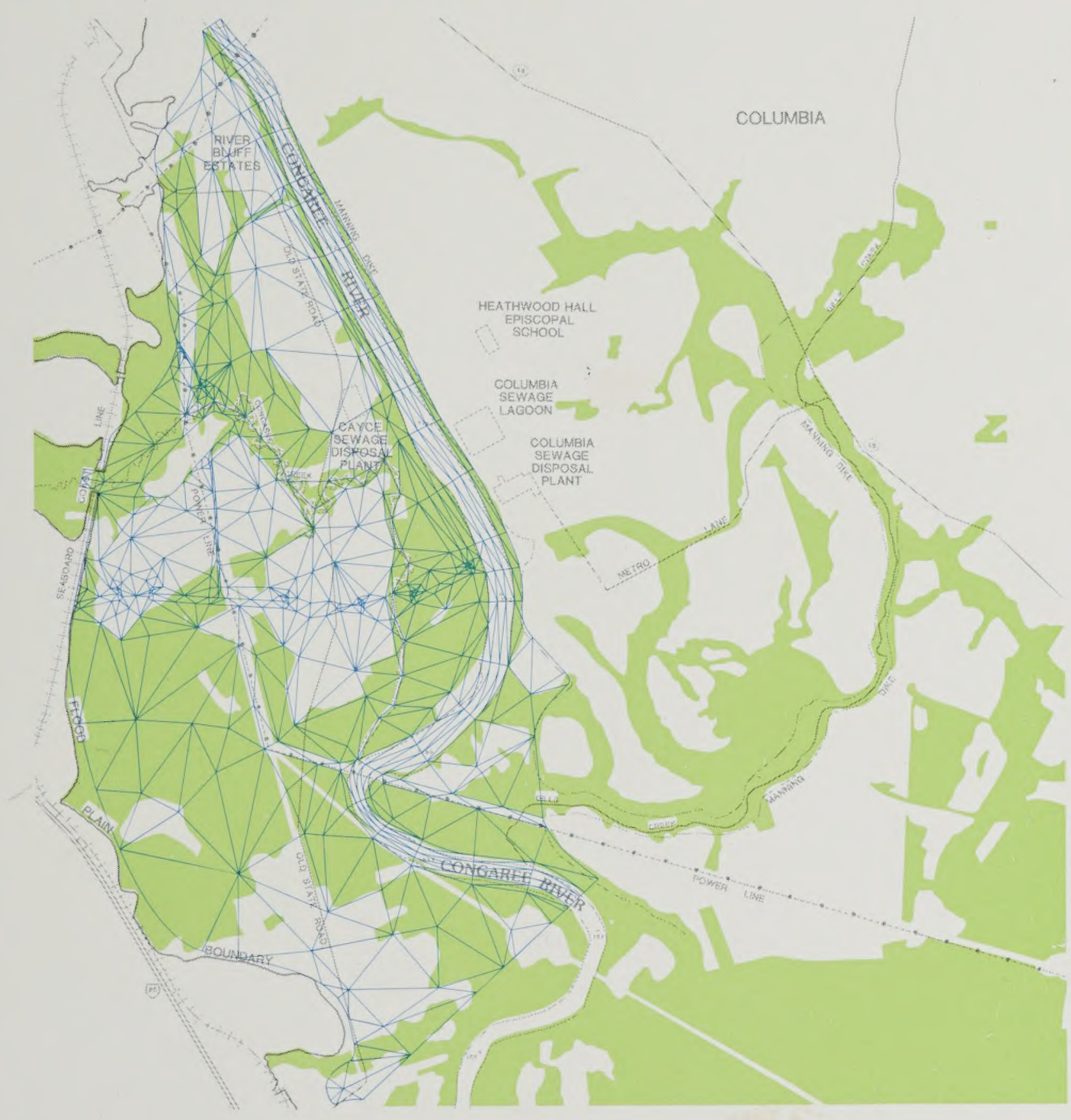

U.S. GEOLOGICAL SURVEY

Water-Resources Investigations Report 84-4280 


\section{CONVERSION FACTORS AND ABBREVIATIONS OF UNITS}

The following factors may be used to convert the inch-pound units published herein to the International system of units (SI).

\section{Multiply inch-pound units}

\section{foot ( $f t$ )}

\section{square foot ( $f t^{2}$ )}

foot to the one-half power

per second ( $f t^{1 / 2} / \mathrm{s}$ )

foot per second ( $f t / s$ )

foot per square second ( $f t / s^{2}$ )

cubic foot per second $\left(\mathrm{ft}^{3} / \mathrm{s}\right)$

mile ( $\mathrm{mi}$ )

square mile $\left(\mathrm{mi}^{2}\right)$

acre

slug per cubic foot

( $s l u g / f t^{3}$ )

pound second per square foot $\left(1 b \cdot s / f t^{2}\right)$

\begin{tabular}{c} 
By \\
\hline 0.3048 \\
0.0929 \\
0.5521 \\
0.3048 \\
0.3048 \\
0.02832 \\
1.609 \\
2.590 \\
4,047 \\
0.5154
\end{tabular}

478.7
To obtain SI units

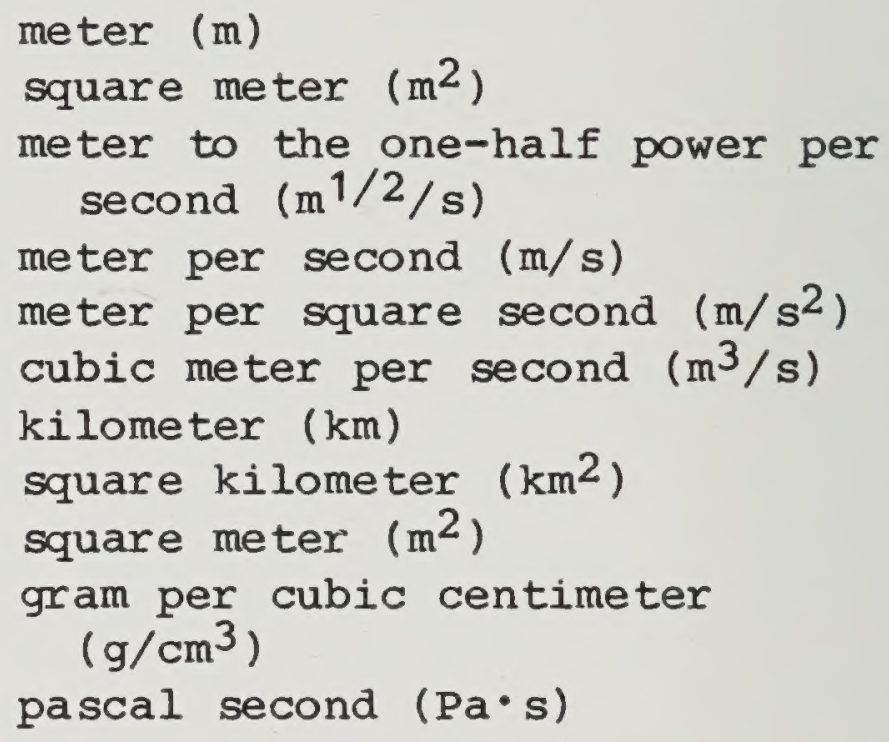

\section{National Geodetic Vertical Datum of 1929 (NGVD of 1929).--A geodetic} datum derived from a general adjustment of the first-order level nets of both the United States and Canada, formerly called mean sea level. NGVD of 1929 is referred to as sea level in this report. 
IMPACT OF THE PROPOSED I-326 CROSSING

ON THE 500-YEAR FLOOD STAGES OF THE

CONGAREE RIVER NEAR COLUMBIA， SOUTH CAROLINA

By Curtis S. Bennett III

U.S. GEOLOGICAL SURVEY

Water-Resources Investigations Report 84-4280

Prepared in cooperation with the

SOUTH CAROLINA DEPARTMENT OF HIGHWAYS AND PUBLIC TRANSPORTATION

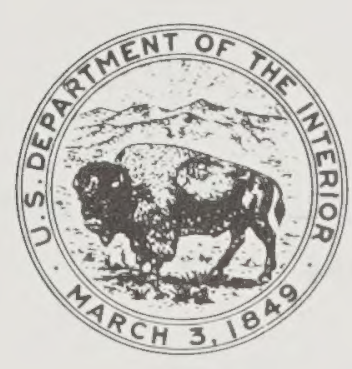

Columbia, South Carolina

1984 


\author{
UNITED STATES DEPARTMENT OF THE INTERIOR \\ DONALD PAUL HODEL, Secretary \\ GEOLOGICAL SURVEY \\ Dallas L. Peck, Director
}

For additional information

write to:

District Chief

U.S. Geological Survey, WRD

1835 Assembly Street, Suite 658

Columbia, South Carolina 29201
Copies of this report can be purchased from:

Open-File Services section U.S. Geological Survey Federal Center, Box 25425 Denver, Colorado 80225

(Telephone: 303/234-5888) 
Abstract. . . . . . . . . . . . . . . . . . . . . . . . . . . . . . 1

Introduction. . . . . . . . . . . . . . . . . . . . . . . . . . . . . . 2

Model description . . . . . . . . . . . . . . . . . . . . . . . . . . . 2

Flow equations . . . . . . . . . . . . . . . . . . . . . . . . . . . 3

Numerical solution of the flow equations . . . . . . . . . . . . . 4 4

Description of the study area . . . . . . . . . . . . . . . . . . 6

General site description . . . . . . . . . . . . . . . . . . . 6

Interstate Route 326 roadway system. . . . . . . . . . . . . . 6

Hydrology of the study area . . . . . . . . . . . . . . . . . . 10

Flood data . . . . . . . . . . . . . . . . . . . . . . 10

Flood frequency. . . . . . . . . . . . . . . . . . . . . . . 11

Application of the finite-element model to the proposed Interstate

Route 326 crossing of the Congaree River. . . . . . . . . . . . . . 11

Outline of the modeling. . . . . . . . . . . . . . . . . 11

Data collection. . . . . . . . . . . . . . . . . . . . . . 11

Network layout . . . . . . . . . . . . . . . . . . . . . . . . 13

Boundary conditions and model coefficients . . . . . . . . . . . 13

Results of the simulations. . . . . . . . . . . . . . . . . . . . 14

Interpretation of the results. . . . . . . . . . . . . . . . 14

October 1976 flood with the Manning dike in place. . . . . . . . 14

500-year flood with the Manning dike in place. . . . . . . . . 16

Relative effects of the highway embankments. . . . . . . . . . . 21

Summary and conclusions . . . . . . . . . . . . . . . . . . . . . 21

References. . . . . . . . . . . . . . . . . . . . . . . . . . . 22 


\section{ILLUSTRATIONS}

Figure 1. Map of Congaree River near Columbia, S.c. . . . . . .

2. Map of Congaree River flood plain near Columbia, S.C., showing proposed bridges... . . . . . . . . . .

3. Graph of frequency curve for the Congaree River at Columbia, S.C. . . . . . . . . . . . . . . . .

4. Map of finite-element network, Manning Dike in place, 500-year flood... . . . . . . . . . . .

5. Map of finite-element network, Manning dike, and highway embankments in place, 500-year flood ........

6. Graph of main channel water-surface profiles for indicated conditions . . . . . . . . . . . .

PLATES

Plate 1. Map of computed velocity field and water-surface elevations, Congaree River near Columbia, S.C., Manning dike in place, 500-year flood.

2. Map of computed velocity field and water-surface elevations, Congaree River near Columbia, S.C., Manning dike, and highway embankments in place, 500-year flood.

3. Map of backwater, Congaree River near Columbia, S.C., Manning dike, and highway embankments in place, 500-year flood.

\section{TABLES}

Table 1. Bridges proposed for the Interstate Route 326 crossing of the flood plain of the Congaree River . . . . . . .

2. Hydraulic properties of the bridges across the flood plain of the Congaree River with the Manning dike in place for the 500-year flood................

3. Water-surface elevations (without and with highway embankments) and backwater at various locations with the Manning dike in place for the 500-year flood . . . . . 


\author{
IMPACT OF THE PROPOSED I-326 CROSSING \\ ON THE 500-YEAR FLOOD STAGES OF THE \\ CONGAREE RIVER NEAR COLUMBIA, SOUTH CAROLINA
}

By Curtis S. Bennett III

ABST RACT

A two-dimensional finite-element surface-water flow modeling system based on the shallow-water equations was used to study the hydraulic impact of the proposed Interstate Route 326 crossing of the Congaree River near Columbia, South Carolina on the 500-year flood. The rapid expansion of the flood plain of the Congaree River upstream from the proposed highway crossing, a dike system on the left bank, and highly variable roughness combine to cause significant lateral velocities and variations in stage during floods. Thus, use of a two-dimensional model was required to adequately describe the hydraulic impact of the Interstate crossing.

Infrared aerial photography was used to define regions of homogeneous roughness in the flood plain. Finite-element networks approximating flood-plain topography were designed using elements of three roughness types. High-water marks established during an 8-year flood that occurred in October 1976 were used to calibrate the model.

The 500-year flood $(630,000$ cubic feet per second) was simulated using the dike on the left bank as the left boundary and the right edge of the flood plain as the right boundary. Simulations were performed without and with the proposed highway embankments in place. Detailed information was obtained about backwater effects upstream from the proposed highway embankments, changes in flow distribution resulting from the embankments, and velocities in the vicinity of the bridge openings.

The results of the study indicate that the four bridge openings in the right flood plain should be adequate to handle the 500-year flood flow. Forty percent of the flow passes through the main channel bridge. The remaining 60 percent of the flow passes through the three overflow bridges. Average velocities in the bridge openings ranged from 3.4 feet per second to 6.9 feet per second with a maximum vertically averaged velocity of 9.3 feet per second occurring at the right edge of one of the overflow bridges. Backwater created by the highway embankments in the flood plain varies from 0.4 foot upstream of the main channel bridge to 1.2 feet on the downstream side of a large island in the flood plain. 


\section{INT RODUCTION}

A two-dimensional finite-element surface-water flow modeling system based on the shallow-water equations was used to study the hydraulic impact of the Interstate Route 326 crossing of the Congaree River flood plain near Columbia, S.C. for the discharge and stages associated with the 500-year flood. A prior report by Lee and Bennett (1981) used an earlier version of this model to evaluate the stage and flow distribution of a flood discharge equal to the flood of record (1908 flood). The discharge of the flood of record is approximately equal to the computed discharge of the 100-year flood.

The rapid expansion of the flood plain of the river upstream from the proposed highway crossing, the dike system on the left bank, and highly variable roughness combine to cause significant lateral velocities and variations in stage during floods. A sewage disposal plant and a subdivision are located in the flood plain above the proposed highway crossing. These features create a complex system that requires the use of a two-dimensional model to obtain a more precise evaluation of stage and flow distribution in the study area than can be obtained by one-dimensional backwater and conveyance techniques.

The assistance of the following individual and organizations in making data available for this study is gratefully acknowledged: W. H. Hulbert, South Carolina Department of Highways and Public Transportation; and the U.S. Army Corps of Engineers.

Throughout this report, the words "right" and "left" refer to positions that would be reported by an observer facing downstream. Elevations refer to NGVD (National Geodetic Vertical Datum) of 1929. A list of factors for converting inch-pound units to metric units is provided at the front of the report. All data supporting the conclusions of this report are available in the files of the South Carolina District office of the U.S. Geological Survey at Columbia, S.C.

\section{MODEL DESCRIPTION}

The core of the modeling system FESWMS, which is under development by the Geological Survey, is a two-dimensional finite-element surface-water flow model based on the work of Norton and King (1973), Norton and others (1973), Tseng (1975), King and Norton (1978). Around this core the Geological survey has developed pre- and postprocessing programs which make the system accessible to the user. Preprocessing programs place input data in an appropriate form for the flow model and plot maps of finite-element networks and associated data. Postprocessing programs plot maps of velocity vectors, water-surface contour lines, lines of equal backwater and drawdown, discharge at specified cross sections, and observed high-water marks.

The formulation and development of the flow model have been reported elsewhere; therefore, only the equations solved and a brief outline of the technique used to solve them are presented here. 


\section{Flow Equations}

Under the usual assumptions (for example, hydrostatic pressure and momentum correction factors of unity), two-dimensional surface-water flow in the horizontal plane is described by three nonlinear partial-differential equations, two for conservation of momentum and one for conservation of mass (Pritchard, 1971):

$$
\begin{aligned}
& \frac{\partial u}{\partial t}+\frac{\partial u}{\partial x}+\frac{\partial u}{\partial y}+\frac{\partial h}{\partial x}+\frac{\partial z_{0}}{\partial x}-\frac{1}{\rho h}\left[\frac{\partial}{\partial x}\left(\varepsilon_{x x} h \frac{\partial u}{\partial x}\right)+\frac{\partial}{\partial y}\left(\varepsilon_{x y h} \frac{\partial u}{\partial y}\right)\right] \\
& -2 \omega v \sin \phi+\frac{g u}{c^{2} h}\left(u^{2}+v^{2}\right) \frac{1}{2}-\frac{g^{h}}{h} v_{a}{ }^{2} \cos \psi=0, \\
& \frac{\partial v}{\partial t}+\frac{u v}{\partial x}+\frac{v v}{\partial y}+g \frac{\partial h}{\partial y}+\frac{g z_{0}}{\partial y}-\frac{1}{\rho h}\left[\frac{\partial}{\partial x}\left(\varepsilon_{y x h} \frac{\partial v}{\partial x}\right)+\frac{\partial}{\partial y}\left(\varepsilon_{y y h} \frac{\partial v}{\partial y}\right)\right] \\
& -2 \omega u \sin \phi+\frac{\xi v}{c^{2} h}\left(u^{2}+v^{2}\right) \frac{1}{2}-\frac{v_{a}}{h} \sin \psi=0,
\end{aligned}
$$

and

$$
\frac{\partial h}{\partial t}+\frac{\partial}{\partial x}(u h)+\frac{\partial}{\partial y}(v h)=0,
$$

where,

$x, y=$ Cartesian coordinates in the positive east and north directions, respectively (feet),

$t=$ time (seconds),

$\mathrm{u}, \mathrm{v}=$ depth-averaged velocity components in the $\mathrm{x}$ - and $y$-directions, respectively (feet per second),

$h=\operatorname{depth}$ ( feet),

$z_{0}=$ bed elevation (feet),

$\rho=$ density of water (assumed constant) (slugs per cubic foot),

$\omega=$ rate of the Earth's angular rotation (per seconds),

$\phi=$ latitude (degrees),

$g$ = gravitational acceleration (feet per square seconds),

$\mathrm{C}=$ Chezy coefficient (feet to the one-half power per second),

$\varepsilon_{x x} \cdot \varepsilon_{x y} \cdot \varepsilon_{y x} \cdot \varepsilon_{y y}=$ eddy viscosities (pound second per square foot),

$\xi=$ water-surface resistance coefficient,

(nondimensional),

$V_{a}=$ local wind velocity (feet per second), and,

$\psi=$ angle between the wind direction and the $x$-axis

(degrees). 
The two-dimensional surface-water flow equations account for energy losses through two mechanisms: bottom friction and turbulent stresses. The Chezy equation for bottom friction in open-channel flow is extended to two dimensions for use in equations 1 and 2. Equations 1 and 2 also use Boussinesq's eddy-viscosity concept, which assumes the turbulent stresses to be proportional to the mean-velocity gradients.

Boundary conditions consist of the specification of flow components or water-surface elevations at open boundaries and zero flow components or zero normal flow (tangential flow) at all other boundaries, called lateral boundaries. For a time-dependent problem, initial conditions must also be specified. Equations 1 through 3, together with properly specified initial and boundary conditions, constitute a well-posed initial-boundary-value problem.

\section{Numerical solution of the Flow Equations}

Quadratic basis functions are used to interpolate velocity components, and linear basis functions are used to interpolate depth on triangular, six-node, isoparametric elements (mixed interpolation). Model topography is defined by assigning a ground-surface elevation to each element vertex and requiring the ground surface to vary linearly within an element.

The finite-element model requires the specification of a constant chezy coefficient, $C$, and a constant symmetric turbulent-exchange, or eddyviscosity, tensor, e, over each element. Nonisotropic turbulent stresses can be simulated by assigning different values to the components of the eddyviscosity tensor. The eddy-viscosity terms in the momentum equations suppress nonlinear instabilities generated by the convective terms, and nonzero eddyviscosity values are necessary for convergence of the numerical method to a solution. The eddy-viscosity values can influence the results of a simulation; however, optimum values are difficult to determine. In general, increased values serve to increase water-surface slopes. It is also known that eddy-viscosity values should increase with element size.

Flow components are specified at inflow boundary nodes, and water-surface elevations are specified at outflow boundary nodes. In this study, zero normal flow was specified at all lateral boundaries. Isoparametric elements permit the use of smooth, curved lateral boundaries. The improvement in accuracy obtained by using such boundaries, together with the specification of zero normal flow (tangential flow) there, has been documented by Gee and MacArthur (1978), King and Norton (1978), and Walters and Cheng (1978, 1980) for the mixed-interpolation formulation of the surface-water flow equations. 
Galexkin's method of weighted residuals, a Newton-Raphson iteration scheme, numerical integration using seven-point Gaussian quadrature (Zienkiewicz, 1977, p. 200-201), and a frontal solution algorithm using out-of-core storage (Hood, 1976, 1977) are used to solve for the nodal values of the velocity components and depth. The time derivatives are handled by an implicit finite-difference scheme; in the application reported here, however, only the steady-state forms of the equations were solved.

If a finite-element network is not well designed, errors in conservation of mass can be significant because there are only approximately half as many equations for conservation of mass as there are for conservation of momentum in either the $x$ - or $y$-direction. For a well-designed network, however, errors in mass conservation are small. The model has the capability of integrating the discharge across a line following element sides and beginning and ending at element vertices. Thus, conservation of mass can be checked (King and Norton, 1978).

The interested reader may consult the books by Pinder and Gray (1977) and zienkiewicz (1977) for additional information on the finite-element method. 
DESCRIPTION OF THE STUDY AREA

\section{General Site Description}

The Congaree River originates at the confluence of the Broad and Saluda Rivers at Columbia, flows southeastward for 51.5 miles, and joins the wateree River near the head of Lake Marion to form the Santee River. Both the Broad and Saluda River basins are located in the Piedmont region of South Carolina, with headwaters in southwestern North Carolina. The drainage area of the Congaree River at Columbia, 1.7 miles above the study area, is 7,850 square miles. Of this drainage area, 5,240 square miles are in the Broad River basin and 2,520 square miles are in the Saluda River basin.

The reach of the Congaree River studied in this report lies between river miles 166.9 and 173.1 (fig. 1). Zero river mile is defined as the mouth of the Santee River. The reach is between 42.2 and 48.4 miles upstream from where the Congaree River joins the Santee River. The flood plain expands from a width of approximately 0.13 mile at the upper end of the study area to a width of approximately 4 miles at the proposed Interstate Route 326 crossing about 3 miles downstream (fig. 2). The streambed generally consists of alluvial sands blanketed with finer soils. About half the flood plain is covered with a combination of dense timber and underbrush. Most of the rest of the flood plain is occupied by cultivated fields, interspersed among the wooded areas.

The limited residential or commercial development on the left side of the flood plain is partially protected by an earth-fill dike (Manning dike). Existing encroachments include a small subdivision (River Bluff Estates) on the right flood plain at the upper end of the study area, a private school (Heathwood Hall Episcopal School) on the left approximately 1.1 miles upstream of the proposed highway crossing, the city of Cayce sewage disposal plant on the right approximately 1.1 miles upstream of the proposed highway crossing, and the city of Columbia sewage disposal plant on the left approximately 0.3 mile upstream of the proposed highway crossing. Earth-fill dike systems are in place to protect the city of Cayce and the city of Columbia disposal plants during floods not exceeding the 100-year flood. The seaboard Coast Line Railroad tracks, which run generally north and south along the right side of the flood plain, were determined to be above the water-surface elevations produced by the 500-year flood.

\section{Interstate Route 326 Roadway system}

Interstate Route 326 (I-326) will be a part of the Southeastern Beltway system, which extends around the south and east sides of columbia. It will connect I-26 on the southwest side of Columbia with I-77 and I-20 on the northeast side (fig. 1). It will also serve the city as an additional crossing over the Congaree River. 


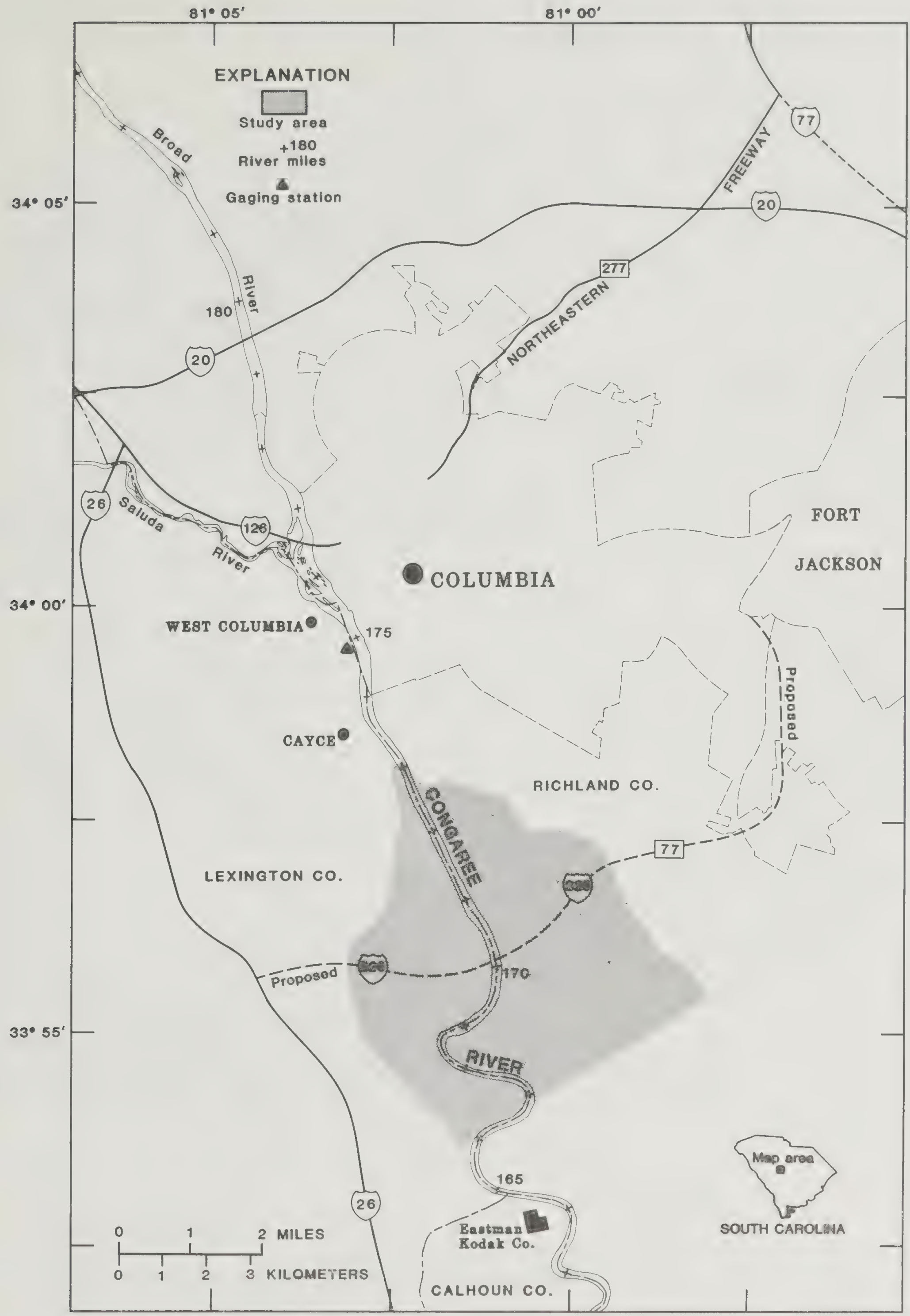

Figure 1.--Congaree River near Columbia, S.C. 


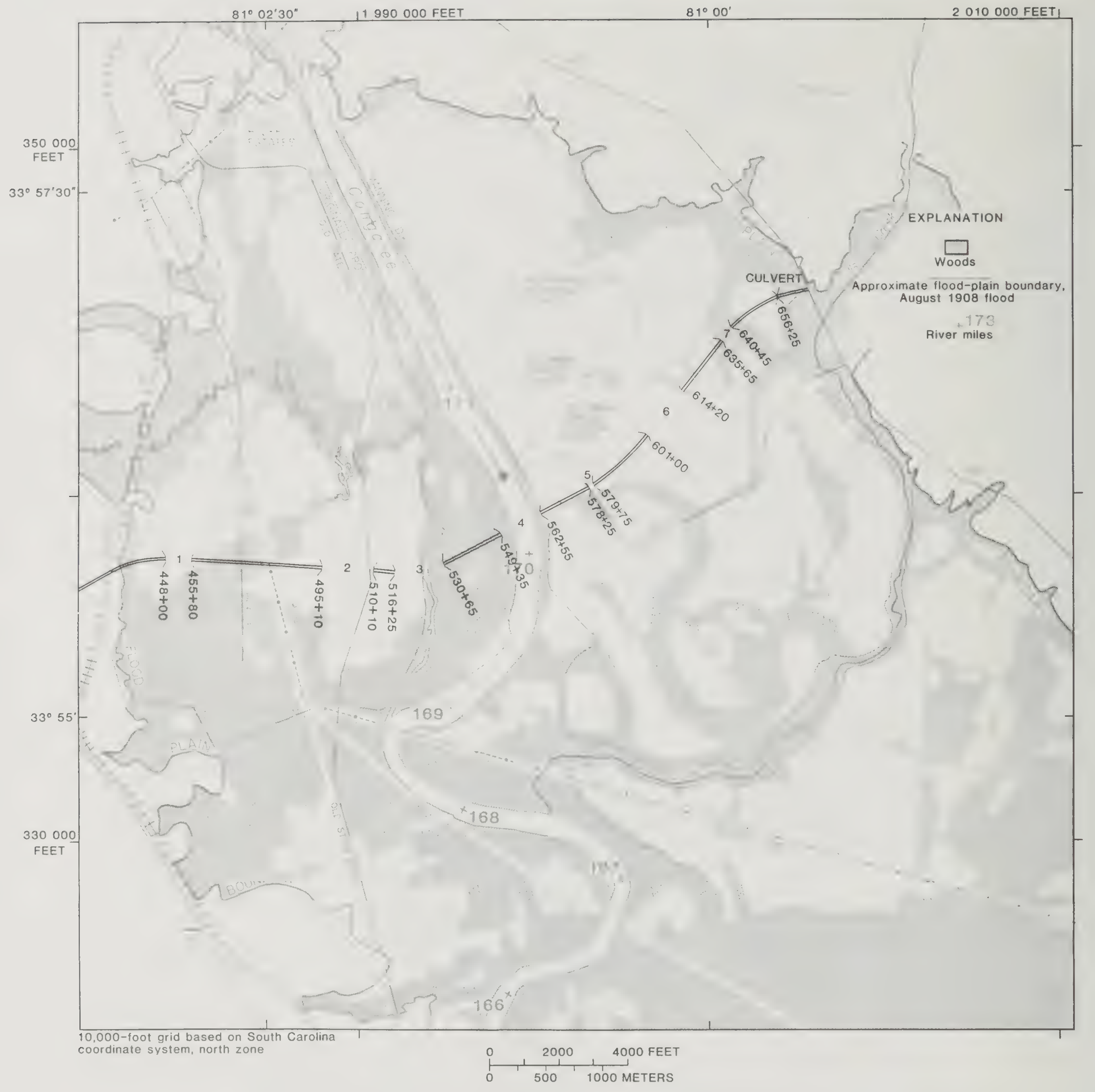

Figure 2.--Congaree River flood plain near Columbia, S.C., showing proposed bridges. 
The I-326 crossing of the Congaree River flood plain will be a controlled-access, six-lane, divided highway. The crossing is approximately at a right angle to the longitudinal axis of the flood plain, with the highway running east and west and the river flowing from north to south. An intersection with the Twelfth Street Extension on the west (Lexington County) flood plain is in the planning stages of development (fig. 2). Twelfth street will run parallel to the river. On the eastern edge of the flood plain, I-326 will intersect South Carolina Route 48, Bluff Road.

There will be seven dual bridges in the flood plain. The effects of the main channel bridge and the three flood-relief bridges on the right flood plain were considered for this study. The number, name, length, and the beginning and ending stations of each bridge are given in table 1 . The bridges are shown in figure 2. Only the main channel bridge is needed during normal flow, but all of these bridges are designed to serve as flood-relief bridges during major floods on the Congaree River.

Table 1.--Bridges proposed for the Interstate Route 326 crossing of the flood plain of the Congaree River

\begin{tabular}{|c|c|c|c|c|}
\hline $\begin{array}{l}\text { Bridge } \\
\text { number }\end{array}$ & Bridge description & $\begin{array}{l}\text { Beginning } \\
\text { station }\end{array}$ & $\begin{array}{l}\text { Ending } \\
\text { station }\end{array}$ & $\begin{array}{l}\text { Length } \\
\text { (feet) }\end{array}$ \\
\hline 1 & Twin overflow bridges 1 & $448+00$ & $455+80$ & 780 \\
\hline 2 & $\begin{array}{l}\text { Twin overpasses over } \\
\text { old state Road } \\
\text { (Road } 5-66 \text { ) }\end{array}$ & $495+10$ & $510+10$ & 1,500 \\
\hline 3 & $\begin{array}{c}\text { Twin bridges over } \\
\text { Congaree Creek }\end{array}$ & $516+25$ & $530+65$ & 1,440 \\
\hline 4 & $\begin{array}{c}\text { Twin bridges over } \\
\text { Congaree River }\end{array}$ & $549+35$ & $562+55$ & 1,320 \\
\hline 5 & $\begin{array}{l}\text { Twin bridges over } \\
\text { Metro Lane }\end{array}$ & $578+25$ & $579+75$ & 150 \\
\hline 6 & Twin overflow bridges 2 & $601+00$ & $614+20$ & 1,320 \\
\hline $\begin{array}{l}7 \\
\text { culvert }\end{array}$ & $\begin{array}{l}\text { Twin overflow bridges } 3 \\
\text { Three 8-foot-by-8-foot } \\
\text { reinforced-concrete } \\
\text { box culverts }\end{array}$ & $635+65$ & $640+45$ & 480 \\
\hline
\end{tabular}




\section{Flood Data}

Streamflow data have been collected at the Geological survey gaging station, Congaree River at Columbia (Fig. 1), from October 1939 to the current year (1983). Gage-height records were collected at a site 1,000 feet upstream from the present gaging station from October 1891 to December 1933. The maximum flow that has occurred since at least October 1891 was caused by a tropical storm in August 1908. The storm caused major flooding throughout the basin. The peak flow of the Congaree River at Columbia was $364,000 \mathrm{ft} / \mathrm{s}$. The water-surface elevation for this flood was 152.8 feet above sea level.

The flood of October 11, 1976, the maximum stage and discharge since April 1936, was used to calibrate the two-dimensional finite-element model. A peak elevation of 142.8 feet above sea level, corresponding to a discharge of $155,000 \mathrm{ft}^{3} / \mathrm{s}$, was recorded at the Congaree River gage at Columbia. A large part of the flood plain in the study area was inundated after the dike along the left side of the main channel was breached in the vicinity of the Columbia sewage disposal plant. High-water marks were established by personnel of the South Carolina Department of Highways and Public Transportation at River Bluff Estates, along old State Road at Congaree Creek, above and below the proposed highway route on the right flood plain, and near the left bank of the main channel at the proposed highway route. High-water marks were also established by U.S. Army Corps of Engineers personnel at River Bluff Estates and later by U.S. Geological Survey personnel near River Bluff Estates, near the Cayce sewage disposal plant, and at the downstream end of the study reach. A peak of 127.0 feet above sea level, which was used to define the lower end of the flood profile, was observed on the staff gage at the Eastman Kodak Company plant at river mile 164.5 .

Congaree Creek, with a drainage area of 136 square miles, empties into the Congaree River from the west between miles 168 and 169. Gills Creek, with an even smaller drainage area, empties into the Congaree River from the east between miles 167 and 168. The maximum peak discharge (since 1959) of Congaree Creek was $1,840 \mathrm{ft}^{3} / \mathrm{s}$. Because of their insignificance compared to the flow of the river, the flows of these creeks were disregarded in this study. 


\section{Flood Frequency}

Numerous dams on the Broad and Saluda Rivers have significantly influenced flood magnitude on the Congaree River. The largest of these structures, Saluda Dam, located 12 miles above the mouth of the Saluda River, may have the most pronounced effect on flood flows. Saluda Dam, completed in 1930 by the South Carolina Electric and Gas Company, forms Lake Murray, which has a surface area of about 51,000 acres at maximum power pool. Since this reservoir is operated for hydropower generation only, inflow during major floods creates temporary storage above maximum operating pool levels. During major floods, safety considerations for the earth-fill dam necessitate releases through spillway gates in addition to discharges through power turbines to lower the reservoir to required maximum pool levels as soon as possible.

The U.S. Army Corps of Engineers performed a Log Pearson Type III frequency analysis using recorded flood discharges which were adjusted for coincidental flood control storage to develop the discharge-frequency curve. The South Carolina Department of Highways and Public Transportation, Federal Highway Administration, and the U.S. Geological Survey agreed to use a discharge of $630,000 \mathrm{ft}^{3} / \mathrm{s}$, determined by the U.S. Army Corps of Engineers for the 500-year flood. The flood frequency curve provided by the U.S. Army Corps of Engineers (R. J., Catoe, oral commun., 1983) is shown in figure 3.

\section{APPLICATION OF THE FINITE-ELEMENT MODEL TO THE PROPOSED INTE RSTATE ROUTE 326 CROSSING OF THE CONGAREE RIVER}

\section{Outline of the Modeling}

High-water marks established during the October 1976 flood $\left(155,000 \mathrm{ft}^{3} / \mathrm{s}\right)$ were used to calibrate the finite-element model. The values of the Chezy coefficients determined during calibration were used for simulation of the 500-year flood $\left(630,000 \mathrm{ft}^{3} / \mathrm{s}\right)$. The flood plain configuration used for the 500-year flood simulations included the Manning dike along the left bank of the main channel in its existing location with the assumption that the dike will be upgraded to withstand a flood of this magnitude. This flood plain configuration was used for simulations without and with the proposed I-326 and Twelfth street highway embankments in place.

\section{Data Collection}

One-dimensional step-backwater profiles for floods of various magnitudes were obtained from the U.S. Army Corps of Engineers for use in approximating the inundation boundaries and estimating downstream boundary water-surface elevations. High-water marks established for the October 1976 flood were assembled. Information was collected from maps and field surveys on studyarea topography, channel cross sections, the location of existing dikes, and proposed highway embankments and spur dikes. Infrared aerial photographs of the study area were made to determine vegetation type and density. 


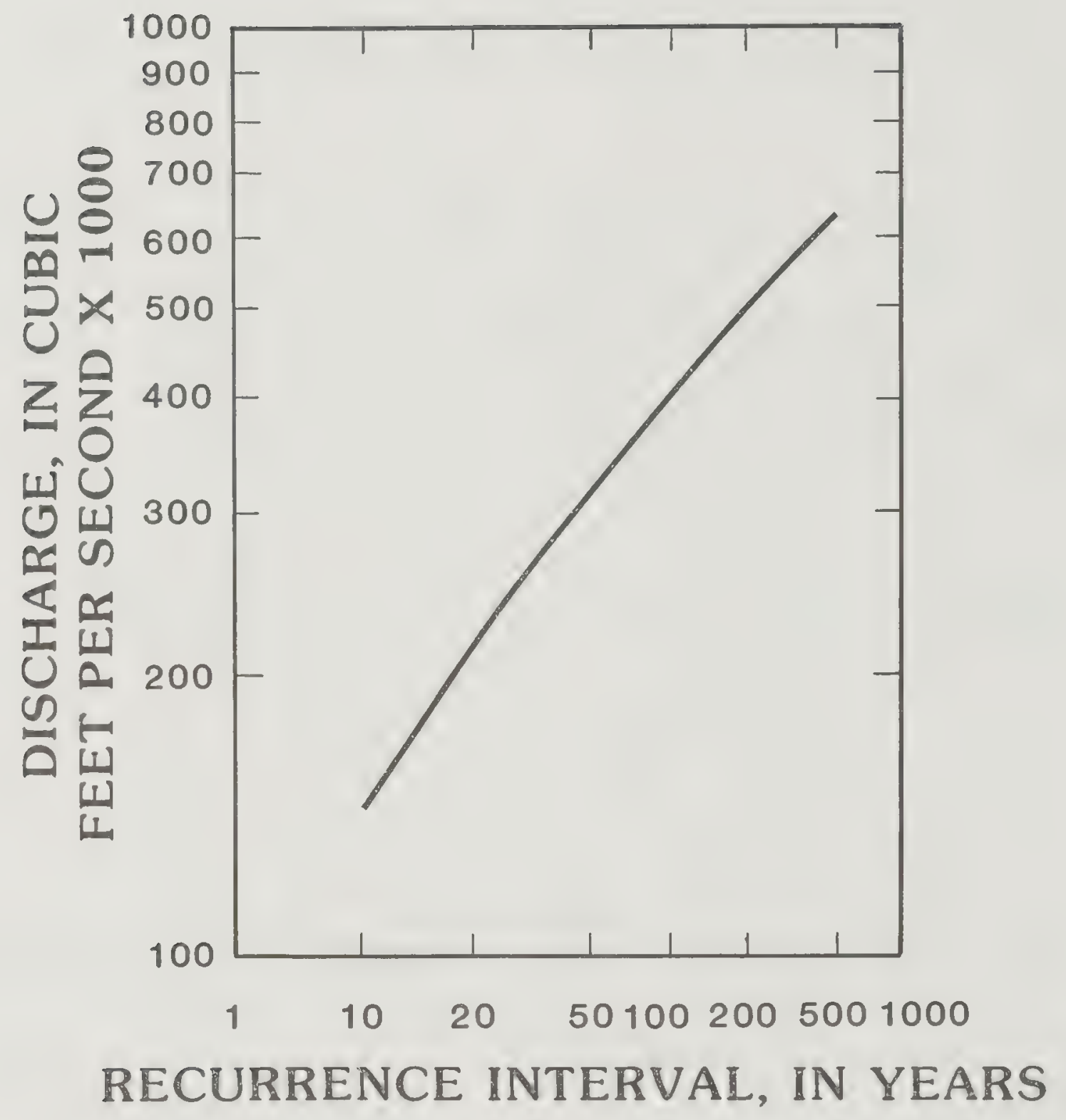

Figure 3.--Frequency curve for the Congaree River at Columbia, S.C. 


\section{Network Layout}

Networks for both model simulations required expansion of the networks developed in the previous study (Lee and Bennett, 1981). The expansions included extending the network upstream and on the right flood plain, and decreasing the size of the island in the flood plain due to the increase in the water-surface elevation. Twelfth street with a bridge over Congaree Creek was included in the expanded networks.

\section{Boundary Conditions and Model Coefficients}

A starting value for each flow component at each inflow node was estimated and then adjusted after the first iteration until the total computed inflow was correct. Because the inflow in all cases was specified only across the width of the main channel (fig. 4), model results were not influenced by the inflow distribution more than two rows of elements downstream from the upstream boundary.

Water-surface elevations at the downstream outflow boundary were estimated from the one-dimensional step-backwater profiles. In each simulation, the downstream water surface was assumed to be horizontal.

As stated above, the solution is obtained by an iterative procedure. Initially the model assumes zero velocity and a constant water-surface elevation equal to the downstream water-surface elevation (downstream boundary condition) at each node. Because of the slope of the flood plain, this procedure would result in negative depths in the upstream part of the model if the correct downstream water-surface elevation was used. Therefore, the initial downstream water-surface elevation was set as high as necessary to avoid this difficulty. The downstream water-surface elevation was decreased for each successive iteration until the specified value was reached. Additional iterations were run until the change in the solution between two successive iterations was less than 1 percent.

The values of the Chezy coefficients determined during the calibration run were used in the two model simulations for the 500-year flood.

Nonzero eddy viscosities are necessary for convergence of the flow model. It is difficult to determine what are realistic values for these coefficients and whether values large enough to ensure convergence are unrealistically large. In general, increasing the values of the eddy viscosities increases the water-surface slope. It was determined by numerical experiment during the previous study (Lee and Bennett, 1981) that, once the values of the eddy viscosities were set high enough to ensure model convergence, the solution was considerably less sensitive to changes in their values than to changes in the values of the chezy coefficients or to changes in network detail. Therefore, the value of $100 \mathrm{lb} \cdot \mathrm{s} / \mathrm{ft}^{2}$, determined in the previous study was used for simulations in this study. 


\section{Interpretation of the Results}

Several factors combine to introduce error into the velocities and watersurface elevations reported here:

1. The assumptions that are made in deriving equations 1 through 3 may not be completely valid throughout the study area.

2. Model discretization involves approximations of prototype topography, roughness, velocities, and depths.

3. Because of model constraints and the limitations of the calibration data, the values of the model coefficients used may distort the results.

4. Boundary conditions, especially the downstream water-surface elevations, are not precisely known.

Knowledge of the hydrology and care in model application have reduced the error from these sources to a minimum. Much more information is obtained than can be obtained from one-dimensional models, but same exror does remain in the computed velocities and water-surface elevations. The velocities reported in this study are vertically averaged velocities. Thus, a high velocity along a spur dike may indicate a potential for scour, but it is not a point velocity at or near the bed.

\section{October 1976 Flood with the Manning Dike in Place}

The high-water marks from the october 1976 flood were used to calibrate the model (Lee and Bennett, 1981, p. 24-27). Although the Manning dike along the left bank of the main channel was breached in several places during the 1976 flood, it was assumed that the outflows were insignificant and could be ignored for modeling purposes. Thus, the Manning dike was treated as a tangential-flow boundary (fig. 4). An upstream inflow of $155,000 \mathrm{ft} / \mathrm{s}$ and a downstream water-surface elevation of 129.2 feet above sea level were used as boundary conditions. Zero inflow was specified for the tributary (Congaree Creek) on the right side of the flood plain. Zero normal flow was specified at all other boundary nodes.

After model convergence was obtained for nominal values of the Chezy coefficients, the values were adjusted by trial and error until the computed water-surface elevations matched the observed high-water marks as closely as possible. The values of the chezy coefficients determined in this calibration process were $63.0 \mathrm{ft} 1 / 2 / \mathrm{s}$ for the main channel, $20.3 \mathrm{ft} 1 / 2 / \mathrm{s}$ for the wooded areas, and $89.7 \mathrm{ft}^{1 / 2} / \mathrm{s}$ for the cleared areas. These values were used in all model runs. 


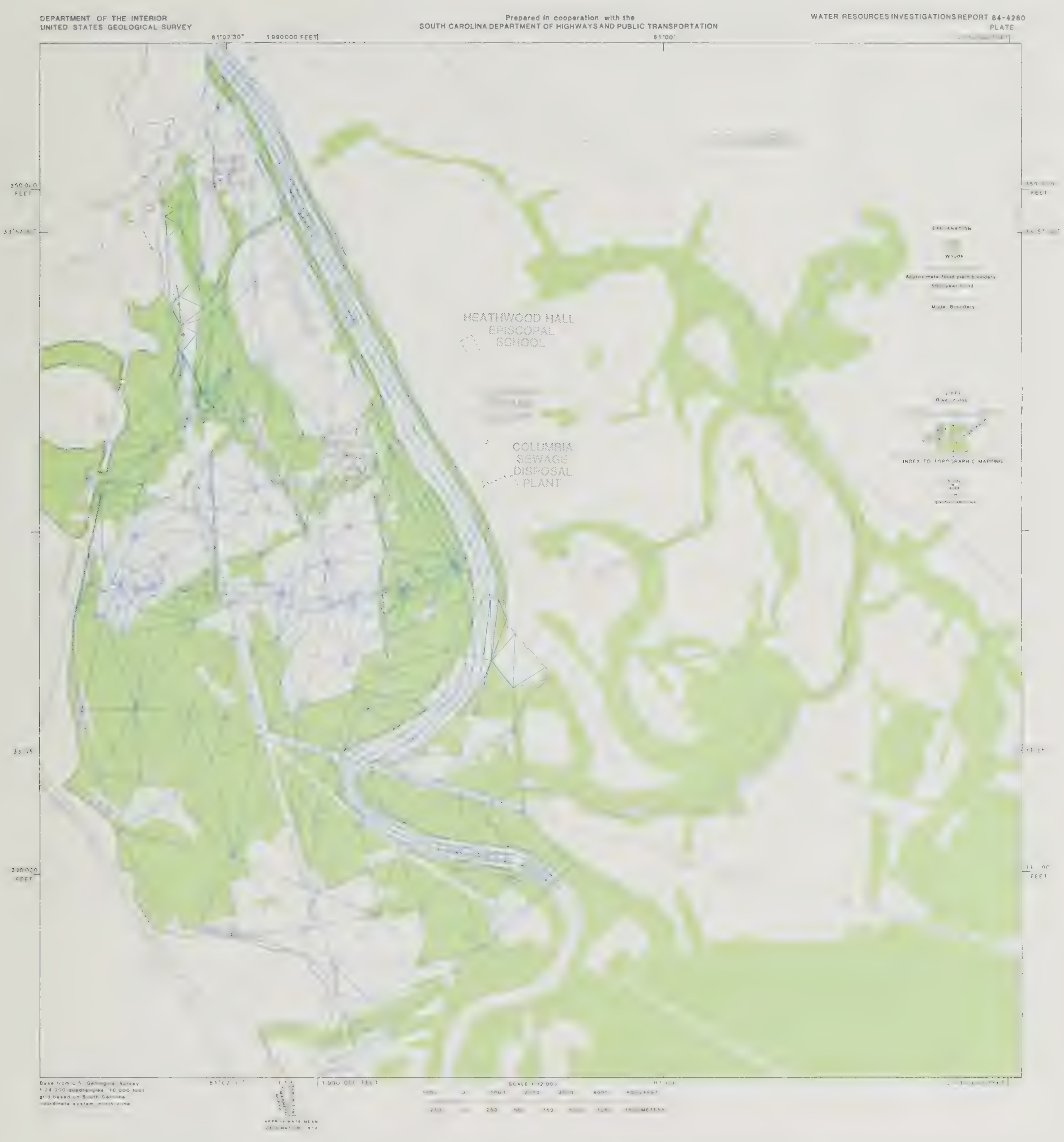

Fig.4.--Finite-Element Network, Manning Dike in place, 500 year flood. 


\section{0-Year Flood with the Manning Dike in Place}

The 500-year flood was simulated undex the assumption that no flow breached the Manning dike. This assumption was based on the South Carolina Department of Highways and Public Transportation's need to quantify the potential effect of the proposed I-326 and Twelfth Street embankments for the condition in which the Manning dike is raised and strengthened to withstand the 500-year flood. In this case, the assumption forces the maximum possible amount of the flow onto the right flood plain.

Model simulations without and with highway embankments were accomplished with the Manning dike in place. The finite-element networks without and with embankments in place are shown in figures 4 and 5, respectively. Bridge lengths are given in table 1. An upstream inflow of $630,000 \mathrm{ft}^{3} / \mathrm{s}$ and a downstream water-surface elevation of 138.8 feet above sea level were used as boundary conditions in both simulations. The values of the chezy coefficients determined in the previous study (Lee and Bennett, 1981) were used for the 500-year flood model simulations.

Plate 1 is a plot of the velocity field and water-surface elevations for the simulation without highway embankments. Plate 2 is a plot of the velocity field and water-surface elevations for the simulation with the highway embankments in place. The continuity-check program option was used to compute the discharge through each of the four I-326 bridge openings and the Twelfth street bridge opening for Congaree creek. The discharge obtained from the continuity check following the line closest to the centerline of the roadway at each opening is given in table 2 .

Ground- and water-surface elevations across each of the I-326 bridge openings were computed by interpolation from model input data and results. These elevations were then used to compute the cross-sectional area, the average velocity, and the average water-surface elevation at each opening (table 2). The maximum vertically-averaged velocities at each opening and at the edges of each opening are also given in table 2.

Water-surface profiles in the main channel for both simulations are shown in figure 6. Plate 3 is a plot of the backwater produced by the highway embankments. This plot is computer generated by determining the difference between water-surface elevations obtained from the simulations with and without the highway embankments in place. Maximum values of the backwater in the main channel and on the flood plain are given in table 3. 


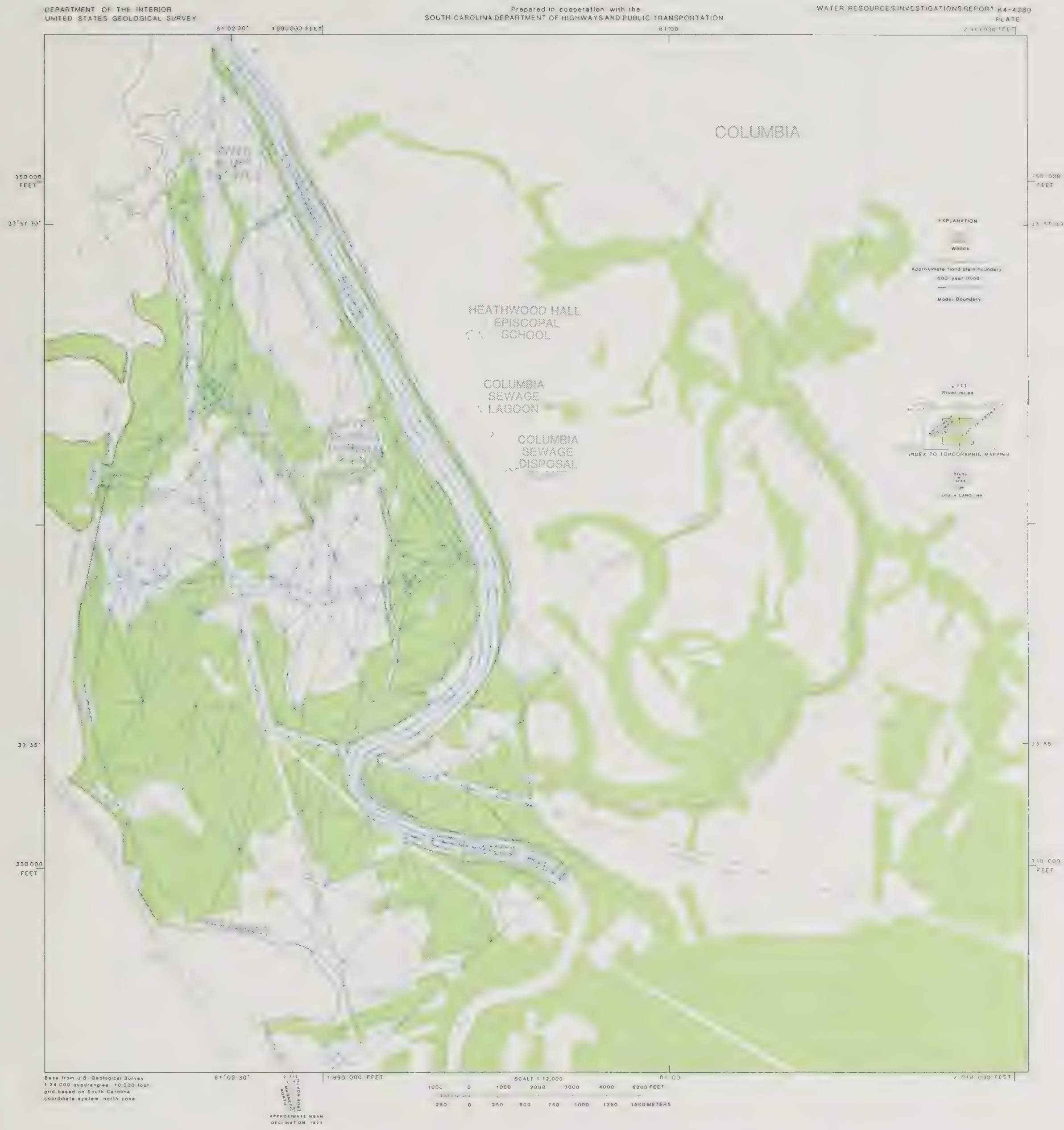

Fig. 5.--Finite-Element Network, Manning Dike, and Highway Embankments in Place, 500 year flood. 


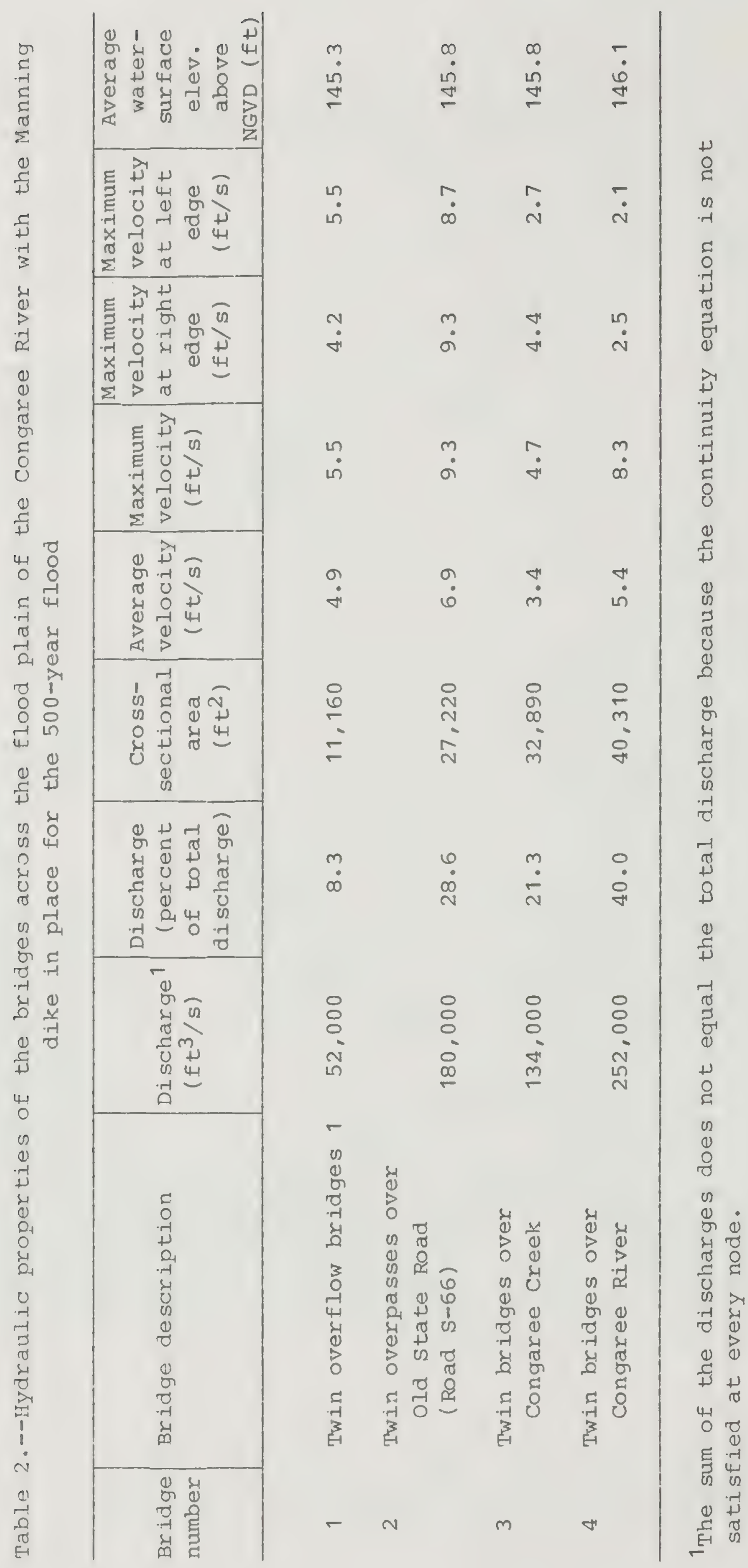




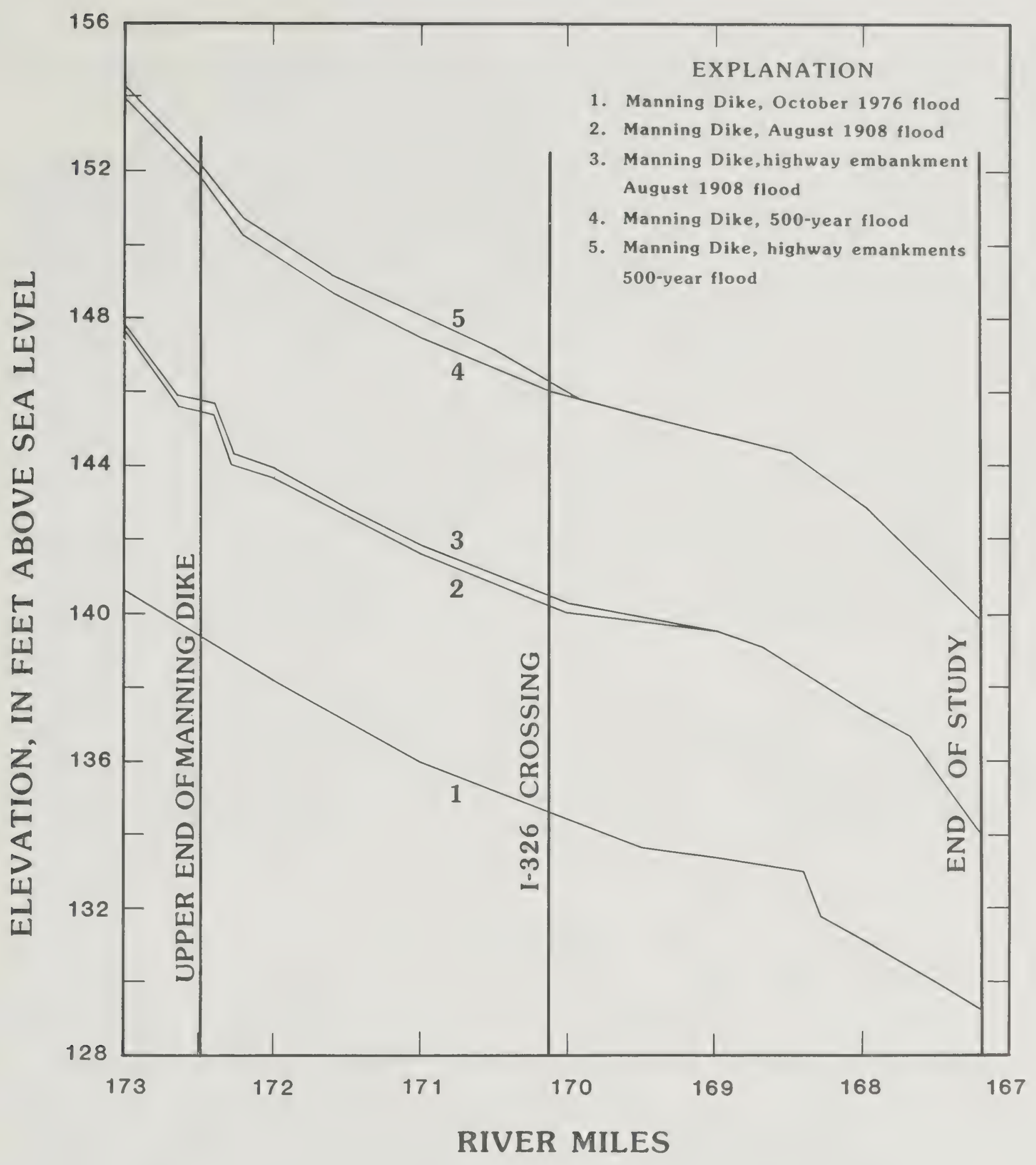

Fig. 6.--Water-surface profiles for the main channel. 
Table 3.--Water-surface elevations (without and with highway embankments) and backwatex at various locations with the Manning dike in place for the 500-year flood

\begin{tabular}{|c|c|c|c|c|}
\hline $\begin{array}{l}\text { Location } \\
\text { reference } \\
\text { number }{ }^{1}\end{array}$ & Location & $\begin{array}{l}\text { Water-surface } \\
\text { elevation above } \\
\text { sea level without } \\
\text { highway embank- } \\
\text { ments (feet) }\end{array}$ & $\begin{array}{l}\text { Water-surface } \\
\text { elevation above } \\
\text { sea level with } \\
\text { highway embank- } \\
\text { ments (feet) }\end{array}$ & $\begin{array}{c}\text { Backwater } \\
\text { as a result } \\
\text { of highway } \\
\text { embankments } \\
\text { (feet) }\end{array}$ \\
\hline 1 & $\begin{array}{l}\text { Location of maximum } \\
\text { backwater in main } \\
\text { channel. }\end{array}$ & 147.7 & $148 \cdot 3$ & 0.6 \\
\hline 2 & $\begin{array}{l}\text { Location of maximum } \\
\text { backwater on flood } \\
\text { plain }\end{array}$ & 146.2 & 147.4 & 1.2 \\
\hline 3 & $\begin{array}{l}\text { Main channel at } \\
\text { twin bridges over } \\
\text { Congaree River }{ }^{2}\end{array}$ & 146.4 & 146.7 & 0.3 \\
\hline 4 & $\begin{array}{l}\text { Cayce sewage } \\
\text { disposal plant }\end{array}$ & 149.8 & 150.4 & 0.6 \\
\hline 5 & $\begin{array}{l}\text { Seaboard Coast Line } \\
\text { bridge over } \\
\text { Congaree Creek }\end{array}$ & 147.1 & 146.9 & -0.2 \\
\hline 6 & $\begin{array}{l}\text { River Bluff } \\
\text { Estates, south side }\end{array}$ & 151.7 & 152.1 & 0.4 \\
\hline 7 & $\begin{array}{l}\text { River Bluff } \\
\text { Estates, east side }\end{array}$ & 152.1 & 152.5 & 0.4 \\
\hline
\end{tabular}

${ }^{1}$ Location reference numbers are shown on plates 1 and 2.

2 The water-surface elevation in the main channel at the twin bridges is an average across the main channel in the case with no highway embankments and an average across the bridge opening in the case with highway embankments. 
The two-dimensional model simulations were accomplished using the 500-year flood discharge without highway embankments in the flood plain and with the highway embankments for I-326 and Twelfth street in place. The flow distribution, as a percent of total flow, through the bridge openings for the 500-year flood, as shown in table 2, is very nearly the same as the flow distribution determined by Lee and Bennett (1981, p. 35) for the 1908 flood. The model simulations for the 1908 flood discharge did not include highway embankments for Twelfth Street; therefore, the Twelfth street structure and embankment may have little effect on the flow distribution through the bridge openings.

Backwater created by the highway embankments was computed by subtracting model water-surface elevations without the embankments in place from those values computed with the embankments in place. Lines of equal backwater are shown on plate 3. Backwater created by the highway embankments in the flood plain east of Twelfth street varies from 0.4 foot upstream from the main channel bridges and River Bluff Estates to 1.2 feet at the junction of Twelfth street with the downstream side of the large island in the flood plain. water-surface elevations and backwater at various locations are listed in table 3.

The embankments for Twelfth street appear to have a marked effect on backwater conditions in the flood plain as shown on plate 3. The Twelfth street embankments create a decrease in water-surface elevation ranging from 0.2 foot to 0.4 foot in the flood plain west of the embankment and an increase in water-surface elevation, up to 1.0 foot, on the east side of the Twelfth street embankment.

\section{SUMMARY AND CONCLUSIONS}

The use of a two-dimensional finite-element model to study the hydraulic effect of the I-326 highway crossing of the Congaree River near Columbia, S.C., yielded a more detailed evaluation of flow distribution and watersurface elevations than can be obtained by one-dimensional step-backwater and conveyance techniques. The capability to describe topography, model

boundaries, highway embankments, and spur dikes using quadratic isoparametric elements is an important advantage of the finite-element flow model. One of the most troublesome problems in model application is the difficulty in determining the amount of network detail necessary to avoid local errors. In general the model gives reasonable results if a trial-and-error process of network refinement is possible. 
The 500-year flood was simulated using the Manning dike on the left bank as the left boundary and the right edge of the flood plain as the right boundary. Although the Manning dike was breached during the 1976 flood, the assumption was made for purposes of this study that this dike will be upgraded to withstand the 500-year flood. This condition forces the maximum possible amount of flow onto the right flood plain. Simulations were performed without and with the proposed highway embankments in place. Detailed information was obtained about backwater effects upstream from the proposed highway embankments, changes in flow distribution resulting from the embankments and velocities in the vicinity of the bridge openings. Hydraulic properties of the bridges across the flood plain with the Manning dike in place are shown in table 2. Water-surface elevations and backwater created resulting from the proposed highway embankments are shown at various locations in table 3.

Water-surface contours and velocity vectors with the proposed highway embankments in place are shown on plate 2. Backwater contours are shown on plate 3. The results of the simulations show that the bridge openings along the I-326 route should be adequate to handle the 500-year flood flow.

The Twelfth Street embankments create unusual and possibly excessive backwater conditions. Backwater, created by the Twelfth Street or I-326 embankments, in the flood plain east of Twelfth street varies from 0.4 foot upstream from the main channel bridges to 1.2 feet at the junction of Twelfth Street with the downstream side of the large island in the flood plain. A decrease in water-surface elevation ranging from 0.02 foot to 0.4 foot occurs in the flood plain west of the Twelfth street embankment. At the present time the Twelfth street embankments are proposed for future construction and are not part of the current I-326 highway construction project.

\section{REFERENCES}

Gee, D. M., and MacArthur, R. C., 1978, Development of generalized free surface flow models using finite element techniques, in Brebbia, C. A. , and others, eds., Finite elements in water resources: International Conference on Finite Elements in water Resources, 2nd, London, 1978, Proceedings: London, Pentech Press, p. 2.61-2.79.

Hood, P., 1976, Frontal solution program for unsymmetric matrices: International Journal for Numerical Methods in Engineering, v. 10, no. 2, p. 379-399.

- 1977, Note on frontal solution program for unsymmetric matrices: International Journal for Numerical Methods in Engineering, v. 11, no. 6 , p. 1055.

King, I. P., and Norton, W. R., 1978, Recent applications of RMA's finite element models for two-dimensional hydrodynamics and water quality, in Brebbia, C. A., and others, eds., Finite Elements in water Resources: International Conference on Finite Elements in water Resources, 2nd, London, 1978, Proceedings: London, Pentech Press, p. 2.81-2.99. 
Lee, J. K., and Bennett, C. S. III, 1981, A finite-element model study of the impact of the proposed I-326 crossing on flood stages of the Congaree River near Columbia, South Carolina: U.S. Geological survey Open-File Report 81-1194, 56 p.

Norton, W. R., and King, I. P., 1973, A finite element model for Lower Granite Reservoir. Computer application supplement and user's guide: Walnut Creek, Calif., Water Resources Engineers, Inc., 90 p.

Norton, W. R., King, I. P., and Orlob, G. T., 1973, A finite element model for Lower Granite Reservoir: Walnut Creek, Calif., Water Resources Engineers, Inc., $138 \mathrm{p}$.

Pinder, G. F., and Gray, W. G., 1977, Finite element simulation in surface and subsurface hydrology: New York, Academic Press, 295 p.

Pritchard, D. W., 1971, Two-dimensional models, in Ward, G. H., Jr., and Espey, W. H., Jr., eds., Estuarine Modeling: An Assessment: Washington, D.C., Environmental protection Agency, Water Quality office, water Pollution Control Research Ser. $16070 \mathrm{DZV}$, p. 22-33.

Tseng, M. T., 1975, Finite element model for bridge backwater computation, v. III of Evaluation of flood risk factors in the design of highway stream crossings: Washington, D.C., Federal Highway Administration Report No. FHWD-RD-75-53, 176 p.

Walters, R. A., and Cheng, R. T., 1978, A two-dimensional hydrodynamic model of a tidal estuary, in Brebbia, C. A., and others, eds., Finite elements in water resources: International Conference on Finite Elements in water Resources, 2nd, London, 1978, Proceedings: London, Pentech Press, p. $2 \cdot 3-2 \cdot 21$.

- - 1980, Accuracy of an estuarine hydrodynamic model using smooth elements: Water Resources Research, v. 16, no. 1, p. 187-195.

Zienkiewicz, O. C., 1977, The finite element method (3rd ed.): London, MCGraw-Hill, 787 p. 





\section{DEPARTMENT OF THE INTERIOR UNITED STATES GEOLOGICAL SURVEY}

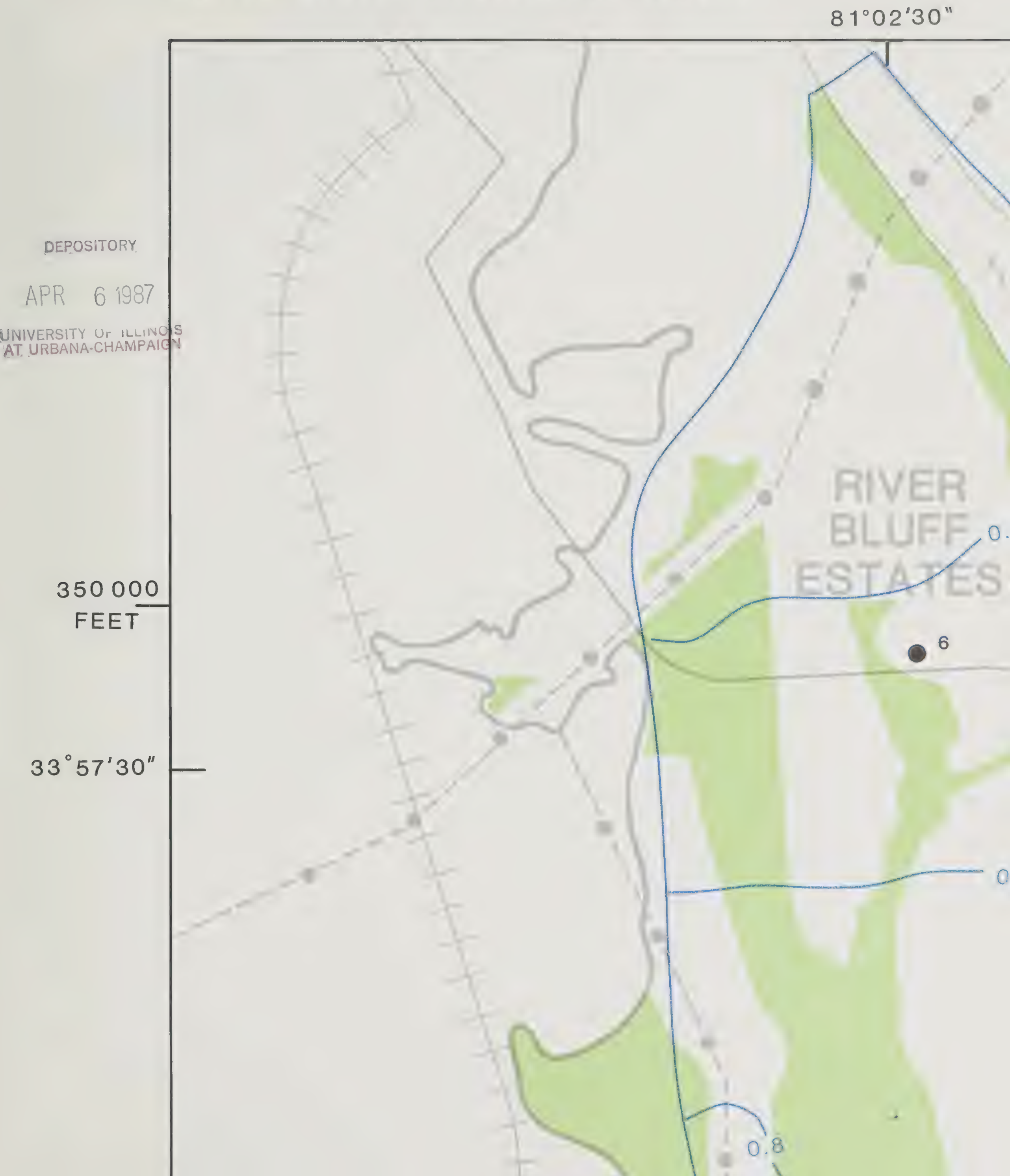




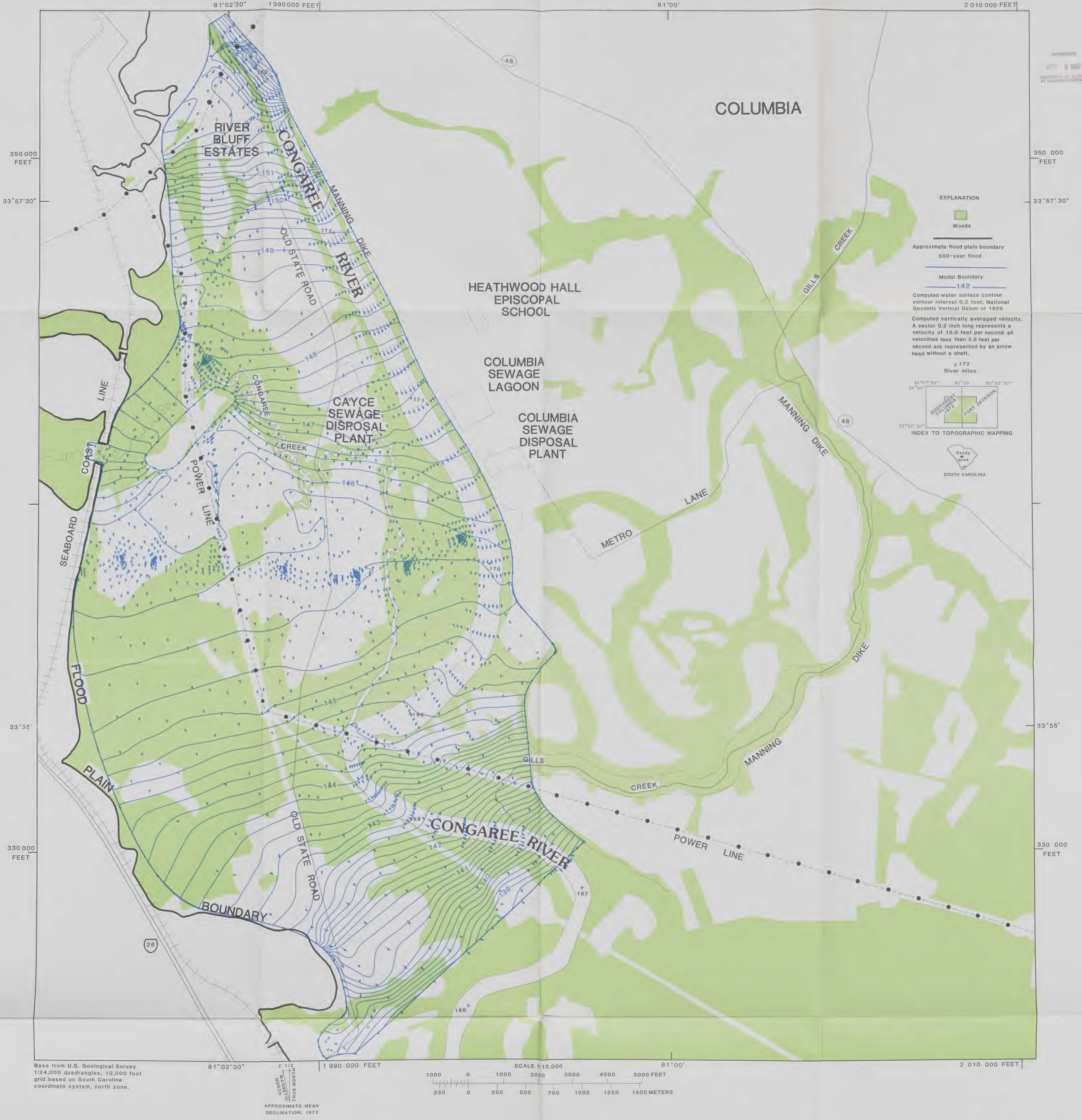




\section{DEPARTMENT OF THE INTERIOR UNITED STATES GEOLOGICAL SURVEY}

$81^{\circ} 02^{\prime} 30^{\prime \prime}$

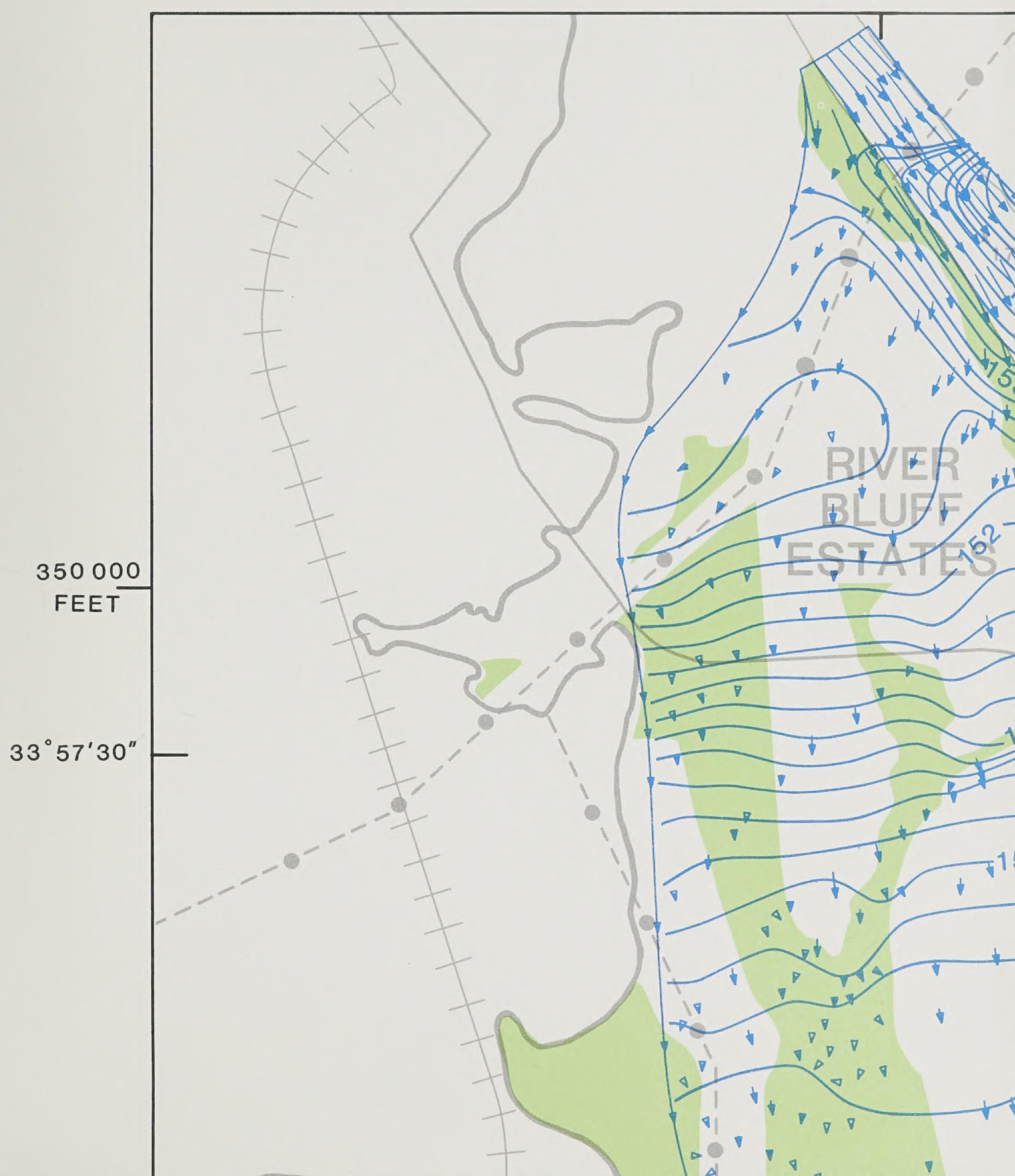




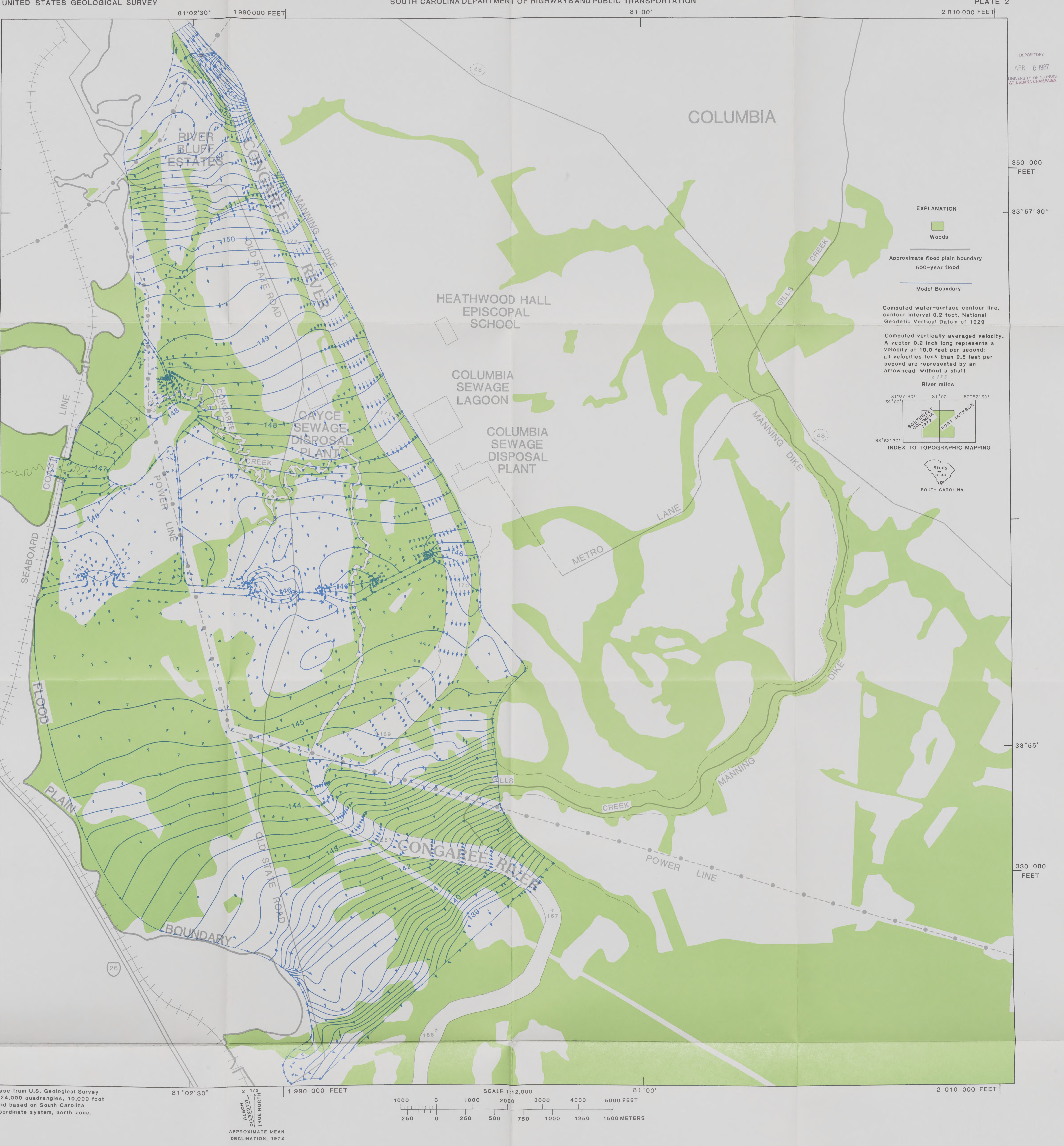

COMPUTED VELOCITY FIELD AND WATER-SURFACE ELEVATIONS, CONGAREE RIVER NEAR COLUMBIA, S.C. MANNING DIKE, AND HIGHWAY EMBANKMENTS IN PLACE, 500-YEAR FLOOD 
DEPARTMENT OF THE INTERIOR

UNITED STATES GEOLOGICAL SURVEY

$81^{\circ} 02^{\prime} 30^{\prime \prime}$

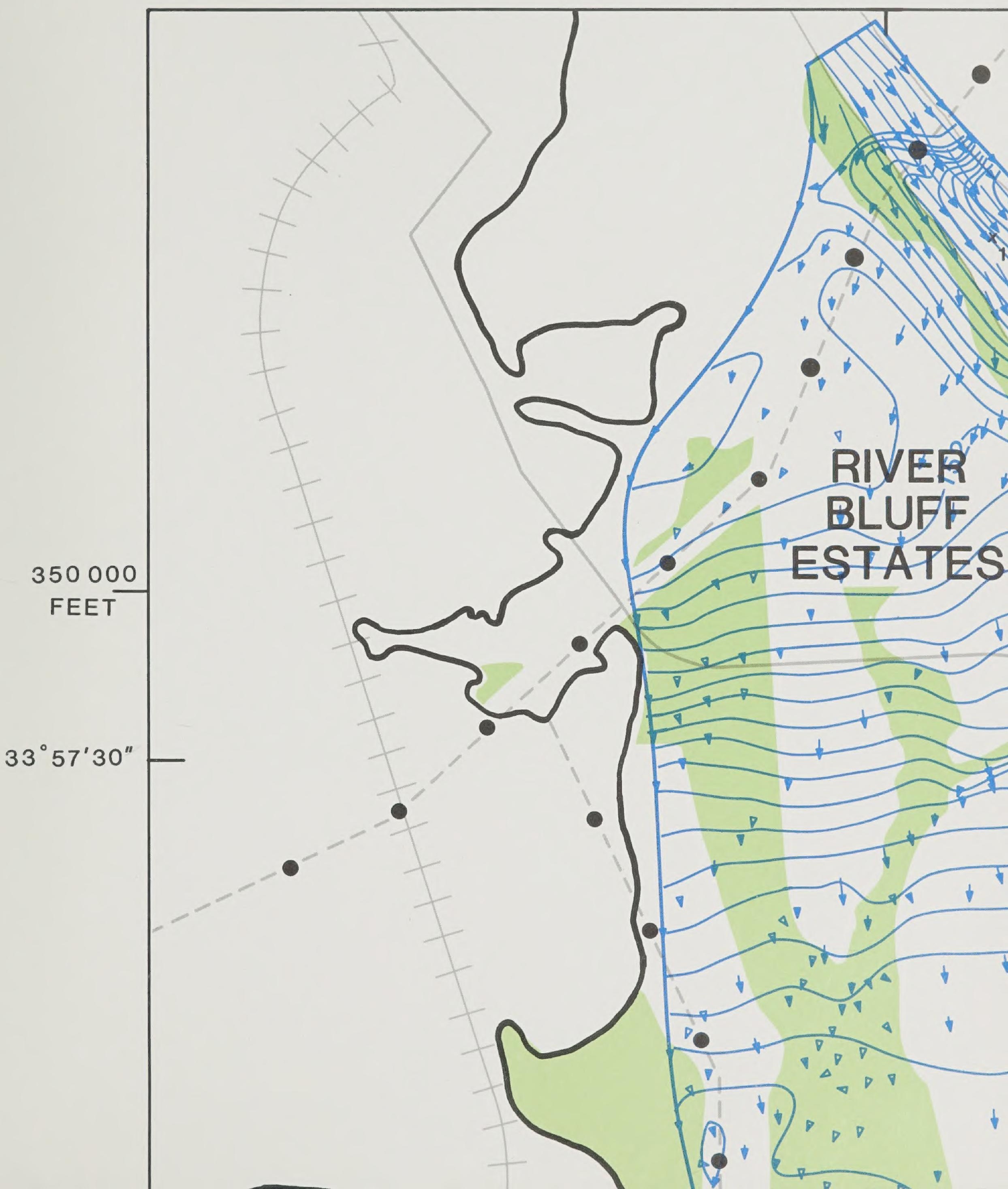




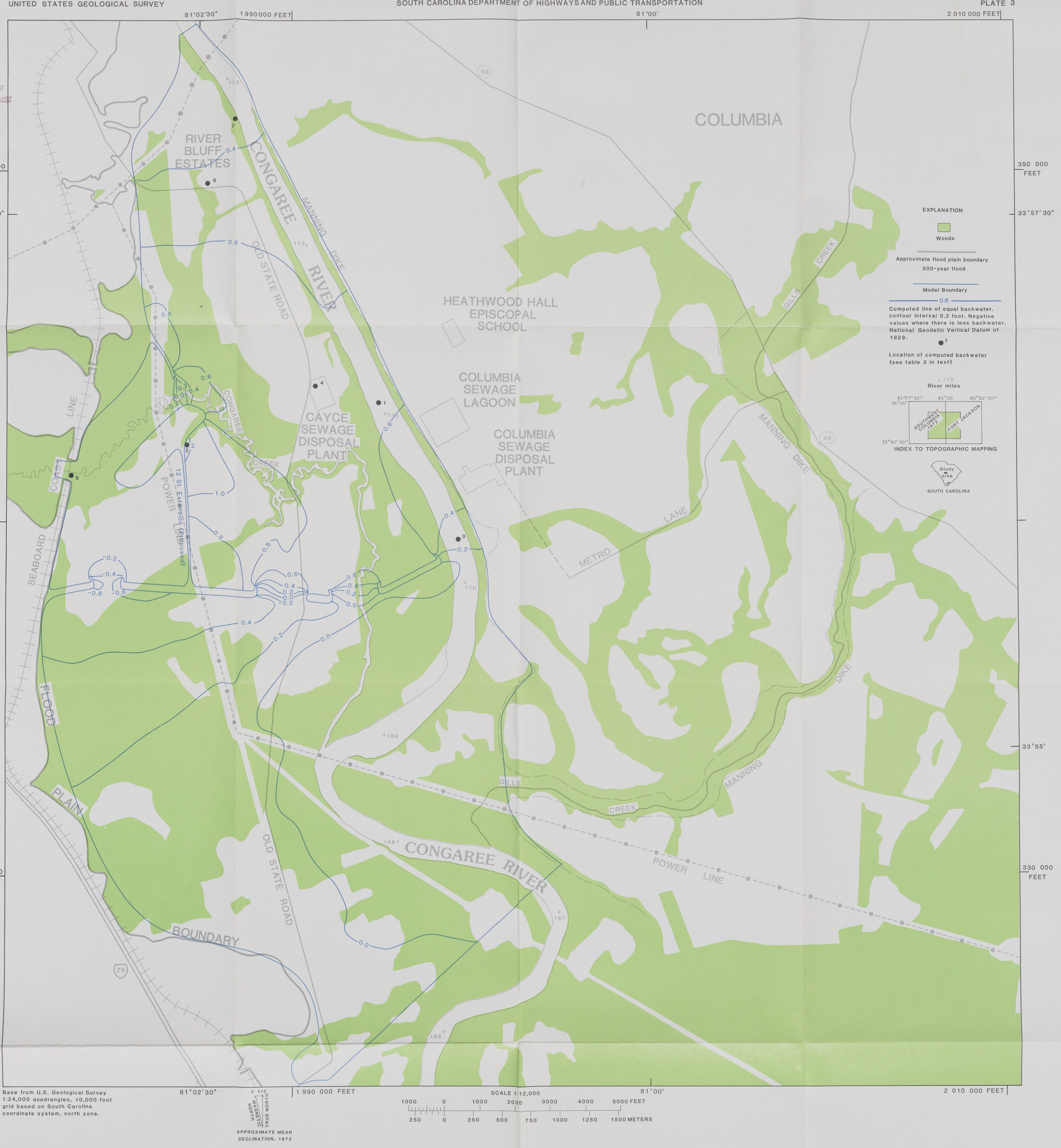

